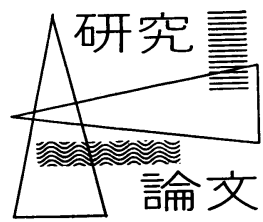

\title{
舶用ディーゼル重油の超音波処理効果 についで
}

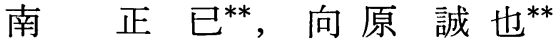 \\ 緒方一彦**，松下正**
}

概 要

舶用ディーゼル重油の超音波処理について，特にこの目的のために開発された装置を用いて，その効果を 実験的に調べた。

超音波処理油が受けている効果を知るためには, 性状の明確な油について, 周波数や照射強度を変えた実 験が望まれるが，ここでは市販の重油を一定の装置で，照射時閒や照射時の油温を種々変化して処理したも のがもつ違いを, ディーゼル機関における噴霧・燃焼特性に関連して調べ, 非照射油のそれと比較した.

適用した試験法は, 比重, 粘度および表面張力試験, 示差熱分析試験, ガスクロマトグラフィー試験, 遠 心沈殿試験, スポット試験, 単一油粒の蒸発・燃焼試験, および実機試験などかなり広範囲にわたっている が, これらの試験の結果, つぎのことが明らかとなった.

超音波処理は, スラッジを多く含む油に対し，スラッジを極微状に粉砕・分散して，油を均質化すること にきわめて効果的である。 また，この結果が僅少ながら液滴の蒸発・燃焼特性を助け，機関の燃焼に影響を 与える．しかし，実験に使用した装置がもつ程度の超音波強度では，油全体を本質的に改善することは困難 である。

\section{On the Effects of Ultrasonic-Treatment on Marine Diesel Fuel Oil}

\author{
by Masami Minami, Seiya Mukohara \\ Kazuhiko Ogata, Tadashi Matsushita
}

\begin{abstract}
Ultrasonic-treatment was seemed one of the most favorable treatment methods to be developed in addition to conventional centrifugal equipments for marine diesel fuel oil, so this experimental study was carried to make clear its effects upon physical and chemical properties of some kinds of heavy fuel oil. A special ultrasonic equipment, named K-7, was applied.

Viscosity, surface tension, gravity and specific heat of fuel were measured strictly and gaschromatography tests, spot tests, evaporation and combustion tests of single oil droplet, and engine firing tests were carried before and after the treatment in accordance with many expectant conditions on board.

The most effective result of the treatment is the fact that large floating sludges in oil are crushed and separated into very small particles by its cavitation effect then oil itself becomes so homogeneous.

Evaporation and combustion qualities of single oil droplet become slightly favorable and this affects on engine performance more or less, but other changes for substantial properties of oil as a whole hardly can be expected by the way of the treatment such as we used here.
\end{abstract}

1. ま え がき

最近の舶用ディーゼル重油のなかには，混合や貯蔵
中に生ずる酸化重合の所産としてかなりのスラッジを 含むものが多い，これがため使用に当たっては, 従来 と異なった飛躍的な前処理法の出現が強くのぞまれて いる.

考えられる方法には，

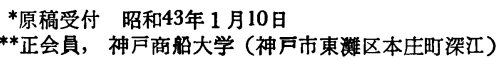


（1）燃焼を阻害している分子を溶解除去する化学 的方法

（2）よりよく燃えるよう燃料分子を極微化する粉 砕法

などがあるが，これに超音波を利用した事例(1)は（2） に属する一つの具体的なあらわれである.

燃料に空洞現象を生ずるような強い超音波を照射す ると, キャビテーション破壊によって燃料中に含まれ ているスラッジが極微状に粉砕されて分散すること， あるいは炭化水素の分子結合が切断されて低分子化す ること, または照射時の分子間の摩擦のため表面帯電 が起こり, 生ずる反発力は霧化を助けることなどの可 能性が予想される。 しかし, その程度およびこれと燃 焼との関連性については, すでに各方面で研究されて いるようであるが，いまだその結果を公表されたもの は見あたらない．

この研究は, 以上の見地より, 実際超音波処理油が 受ける諸現象とその効果を, 特にディーゼル機関の噴 霧の微粒化抒よび燃焼特性に関保する項目について実 験的に究明したものである.

実験は，一つの超音波処理装置において照射時間や 照射時の油温などを変える方法で，いくつかの市販重 油について実施された。

\section{2. 試 験 装 置}

超音波を照射することによって期待される燃料の性 状変化を知るためには, 性状の明確な燃料油について 周波数や照射強度を種々変化した試験を行ならことが 望ましいが，ここでは市販の燃料油を一つの超音波装 置で照射時間や照射時の油温を変えて処理し, 主とし て燃料油の性状分析, 単一油粒の蒸発燃焼試験および 実機試験などを通じて調べることにした。

2.1 超音波発生装置 本装置は磁性物質のジュ 一ル効果を利用した電気音響変換原理を応用して開発

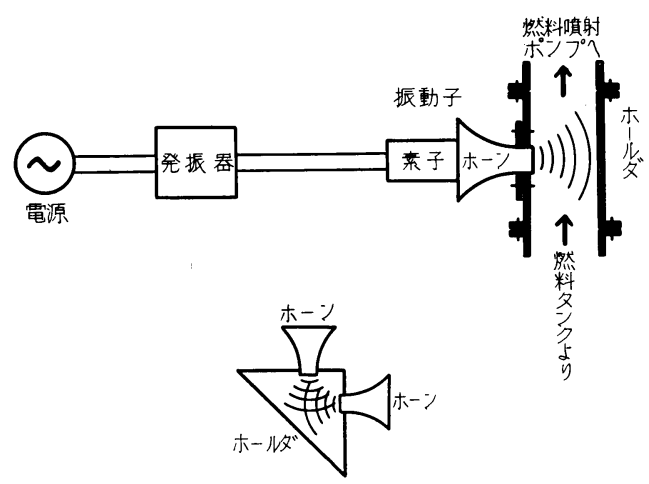

図 1 超音波発生装置概要
された燃料油の超音波処理装置である 図 1 に示すご とく発振器で発生した高周波電力は磁歪振動子で超音 波に変換され，供給油管中を流れる燃料油に照射され る. 実際の装置は図 1 に示寸系統のものを 2 個組み合 わせたものよりなり, その振動子部は図示の要領で木 ルダーに固定している.

この装置の仕様の大要は下記のとおりである.

(1) 処理能力 公称毎時 $100 \sim 150 l$

(2) 発振器 形式 : 全シリコントランジスタ形 強制空冷式 $(\mathrm{K}-7)^{(1)}$, 電源電圧：単相 $100 \mathrm{~V}$, $60 \mathrm{c} / \mathrm{s}$, 最大電流： $6 \mathrm{~A}$, 出力: $300 \mathrm{~W}$, 発振周波 数 : $26 \mathrm{~K} \mathrm{C} \pm 10 \%$

（3）振動子フェライトの粉末を圧縮成形した 素子に特殊クロム処理ステンレス鋼集の振幅拡大 用ホーンをこう着剤で結合して作っている，その 周波数は約 $26 \mathrm{~K} \mathrm{C}$ である. な扔, 振動子の振動数 はフィードバックコイルにより発振回路に帰還し て周波数の安定をはかるようにしている.

2.2 単一油粒の蒸発燃焼試験装置 本装置は単一 油粒の蒸発燃焼試験に際し，小林(2)の用いた方法と原 理的には同じものである．実験に当たり特別に試作し た本装置の概要を図 2 に示寸。ここの装置は細、溶融石 英の系 $(0.2 \phi \mathrm{mm}$ 使用) の先端につるされた油粒に， 一定温度に保持した可動式電気炉を急速に近づけて， 油粒を炉内に入れ，その姿を炉に設けた小空を通して ハイカム $16 \mathrm{~mm}$ 高速度カメラで撮影する仕組よりなっ ている
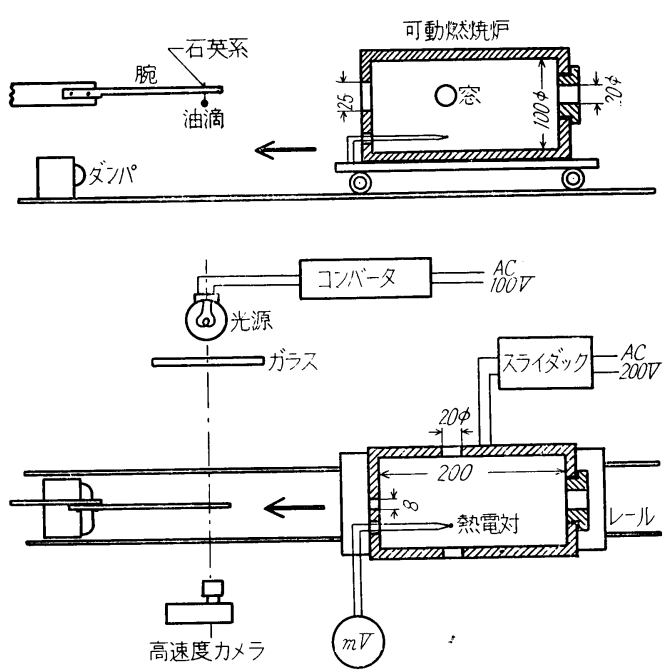

図 2 油粒の蒸発および燃焼試験装置

2.3 供試機関要目 形式: 阪神単筒直接噴射式 四サイクルディーゼル機関, 出力: $25 \mathrm{PS}$, 回転数 : 
$380 \mathrm{rpm}$, シリンダ直径 : $220 \mathrm{~mm}$, 行程 : $350 \mathrm{~mm}$, 圧縮比 $: 12.78$

\section{3. 試 験 方 法}

表 1 に示す性状の然料を用い，照射時間や照射時の 油温を種々変化して試料を採取した。 この場合, 照射 時間は単位時間当たりの流量で規定し，本装置の実用 域の時間流量に近い $90 l / \mathrm{h}$ から極端に照射時間を長く した $0.44 \mathrm{l} / \mathrm{h}$ までの範囲内で変化した，また，超音波 処理時の油温実用範囲にとどめ, A 重油以外の油に ついて $40^{\circ} \mathrm{C}, 60^{\circ} \mathrm{C}$ および $80^{\circ} \mathrm{C}$ の三段階に加熱した.

\section{表 1 供試燃料油の性状}

\begin{tabular}{|c|c|c|c|}
\hline 項 目 & 燃 料 油 & A 重 油 & 重 油 \\
\hline 比重 & $15 / 4^{\circ} \mathrm{C}$ & 0.8510 & 0.9308 \\
\hline 反 & 忘 & 巾䚾: & 中 \\
\hline 引火点 & $\begin{array}{r}P M C \\
{ }^{\circ} \mathrm{C}\end{array}$ & 80 & 96 \\
\hline 粘度 & $\stackrel{\mathrm{cSt}}{@ 50^{\circ} \mathrm{C}}$ & 2.84 & 44.6 \\
\hline 流 動 点 & ${ }^{\circ} \mathrm{C}$ & -22.5 & 0 \\
\hline 残留炭素 & $\%$ & 0.29 & 7.4 \\
\hline 乍 分 & $\%$ & 0.00 & 0.01 \\
\hline 水泥 分 & $\%$ & 0.0 & 0.1 \\
\hline 水 分 & $\%$ & 0.0 & 0.0 \\
\hline イオウ分 & $\%$ & 0.94 & 2.61 \\
\hline
\end{tabular}

まず，超音波照射油が要けている性状変化を知るた め, 主として超音波照射 $\mathrm{A}$ 重油および非照射 $\mathrm{A}$ 重油に ついて, 比重と粘度の測定, 表面張力試験, スポット 試験, 遠心沈殿試験, 示差熱分析試験, およびガスク ロマトグラフィー試験を行ない比較した。 これらの試 験に用いた主な試験機器はつぎのとおりである.

比重 : 浮標式 2 形

粘度 : キャノンフェンスケ動粘度計 表面張力 : デュヌイの張力計

遠心沈殿試験 : 国産式電気遠心沈殿器 示差熱分析試験： D T-10 形(島津製) ガスクロマトグラフ : G C-I C 形, 水素イオン検出器, 多段式自動昇温装 置および熱分解装置付 (島津製)

単一油粒の蒸発および燃焼試験におけ る炉内温度は前者の場合 $500^{\circ} \mathrm{C}$, 後者の 場合 $700^{\circ} \mathrm{C}$ に保持し，その模様をカメラ 速度 50 コマ/秒に収めて解析した.

以上の各試験の試料の採取については 超音波処理することにより，発生する揮 発性ガスの逃出による影響を防止するよ
う十分注意した.

実機の試験においては，A重油を用い，各負荷ごと の燃料消費量, 最高圧力, 排気温度を非照射油および 照射油運転の場合について測定し比較した．ただし， 超音波処理油の使用に当たっては, $30 l / \mathrm{h}$ の割合で連 続 2 回照射処理したものを, さらに照射しながら供給 する方法をとり, 不十分な照射処理で行なうことを極 力避けるよう配慮した.

なお，実機試験は，負荷のみ変化する方法で，回転 数を $300 \mathrm{rpm}$ と $380 \mathrm{rpm}$ の二通りに設定した場合に ついて行ない，篇重に管理した。

表 2 超音波照射 $\mathrm{A}$ 重油の粘度 - 比重 - 表面張力

\begin{tabular}{|c|c|c|c|}
\hline $\begin{array}{l}\text { 超音波照射 } \\
\text { 時 間 }\end{array}$ & 動粘度 $\begin{array}{c}50^{\circ} \mathrm{C} \\
\mathrm{cSt}\end{array}$ & $\begin{array}{l}\text { 比 }{ }^{\circ} \text { 重 } \\
15 / 4^{\circ} \mathrm{C}\end{array}$ & $\begin{array}{l}\text { 表面張力 } \\
\text { dyne/cm }\end{array}$ \\
\hline 非 照 射 & 2.84 & 0.851 & 32.25 \\
\hline $0.111 \mathrm{~h} / \mathrm{L}$ & 2.83 & 0.850 & - \\
\hline 0.222 & 2.83 & 0.850 & - \\
\hline 0.333 & 2.83 & 0.850 & 32.30 \\
\hline 0.444 & 2.83 & 0.850 & - \\
\hline
\end{tabular}

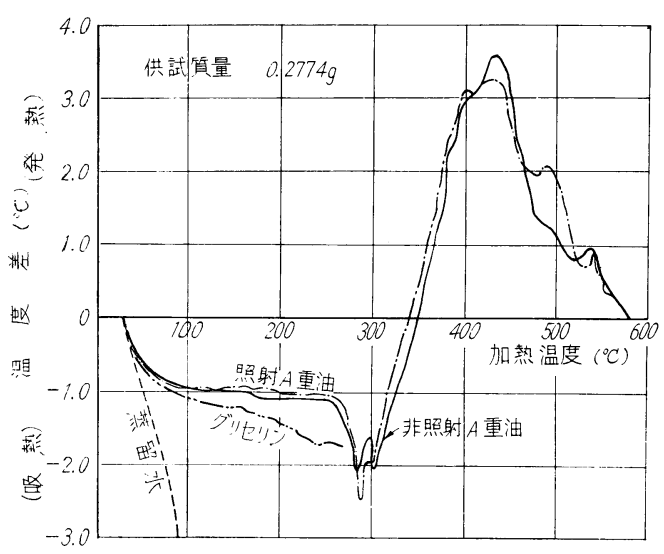

図 3 示差熱分析試験結果 (D T A曲線)

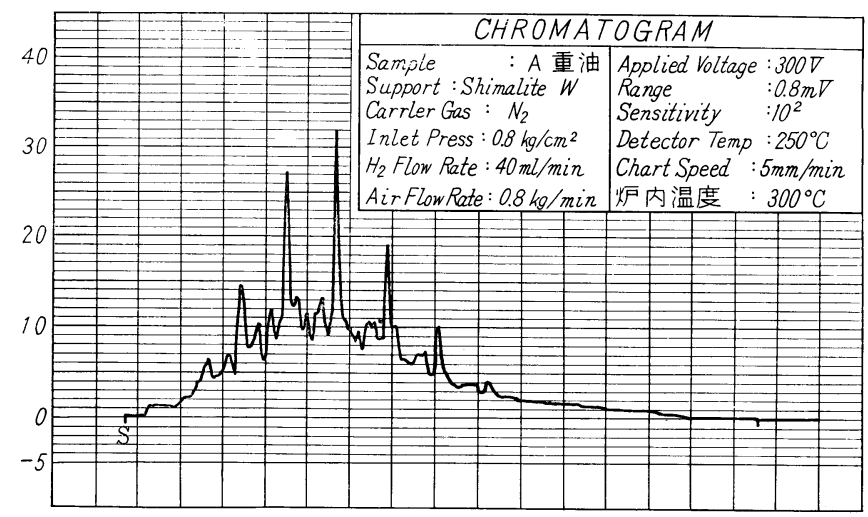

（a）超音波非照射 $A$ 重油

図 4-1 ガスクロマトグラフィー試験結果 


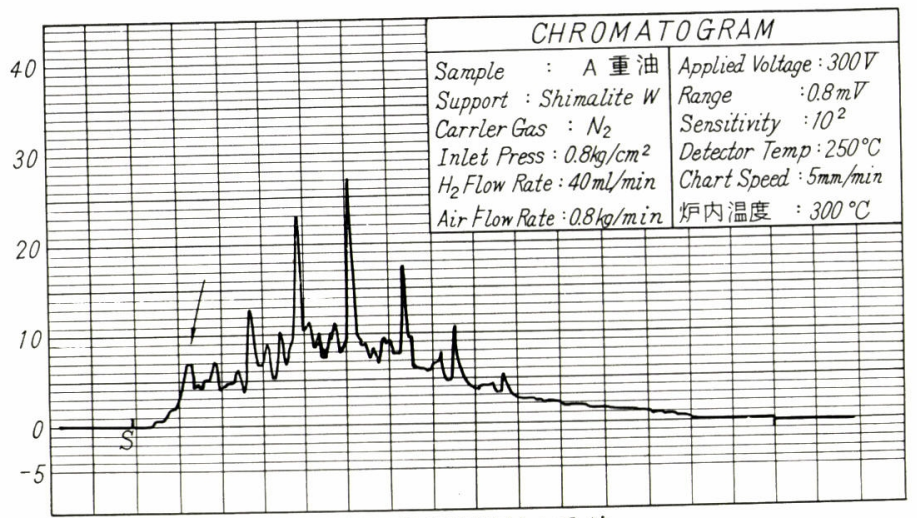

（b）超音波照射 A 重油

図 4-2 ガスクロマトグラフィー試験結果

したものである.

これらは，いずれも超音波を照射 しながら採取した試料に対する直後 の試験結果であり，長時間放置した ものに対する結果は異なるものがあ る.

表 2 にみるごとく，非照射油に対 する照射油の粘度，比重および表面 張力は, 前二者で小さく, 後者で大 きくなる。しかし，その差はいずれ も測定誤差程度のものである。なお 照射時間に対するこれらの值は，極 端に照射時間を増しても同じで，全 く差が認められない.

\section{4. 実験結果およびその考察}

4.1 性状に及ほす影響超音波照射によるキャ ビテーション破壊によって, 燃料が受ける性状の変化 を明らかにする目的で, 表 1 に示すA重油について行 なった試験結果を表 2 および図 3 〜図 6 に示す.

このらち, 表 2 濆霧特性に関係する主な燃料性状 として，粘度および表面張力について調べた結果を比 重とともに示したものであり，図 3 と図 4 は, その熱 的特性㧍よび分子的変化に対寸る示差熱分析試験㧍よ びガスクロマトグラフィー試験の結果である。また, 図 5 と図 6 は, 油中のスラッジに対する破壊効果を示

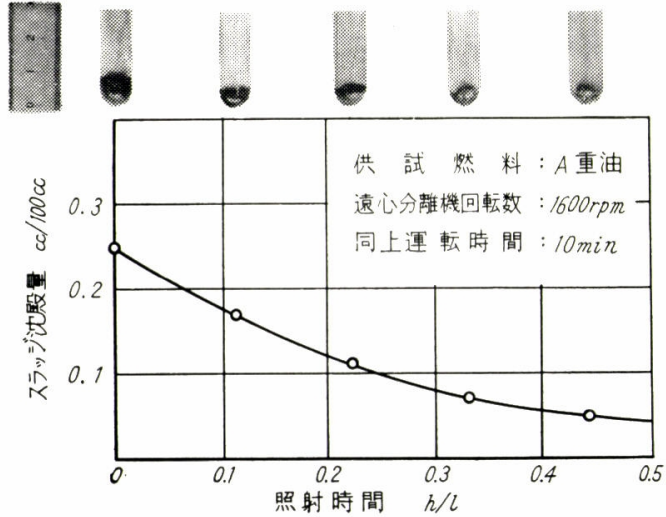

眓 5 遠心沈殿試験結果

\begin{tabular}{|c|c|c|c|c|c|}
\hline 試料番号 & t & 2 & 3 & 4 & 5 \\
\hline 料 & & & & & 8 \\
\hline 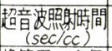 & (非照射) & 0.4 & 0.8 & 1.2 & 1.6 \\
\hline 換算中の直径 & 11.21 & 11.33 & 11.45 & 11.49 & 11.55 \\
\hline
\end{tabular}

（注）試料油 A重油：使用沪紙 No. 5C 比重 0.839 : 滴下量 $10 \mu \mathrm{l}$ 油温度 $33^{\circ} \mathrm{C}$

図6 スポット試験 結果

示差熱分析試験（D T A 法）は，元来固体の熱的特 性を調べるものであるが，A重油（比熱 $0.437 \mathrm{kcal} / \mathrm{kg}$ ${ }^{\circ} \mathrm{C}$ at $20^{\circ} \mathrm{C}$ ) およびこれより比熱の大きいグリセリン (比熱 $0.570 \mathrm{kcal} / \mathrm{kg}^{\circ} \mathrm{C}$ at $20^{\circ} \mathrm{C}$ ) ならびに蒸留水(比 熱 $0.999 \mathrm{kcal} / \mathrm{kg}{ }^{\circ} \mathrm{C}$ at $20^{\circ} \mathrm{C}$ ) に対するこの試験結果 は，図 3 のごとく示される。ただし，図のD T A曲線

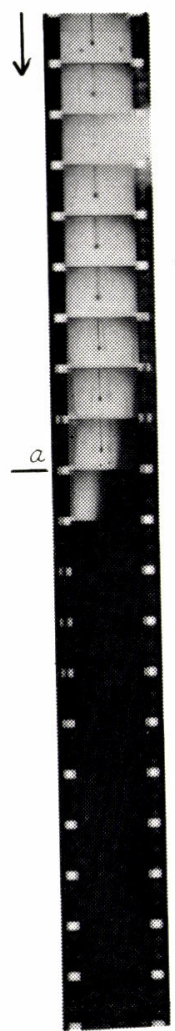

a 点：炉に入る直前 $\mathrm{b}$ 点：炉の寀に見えた瞬間 $\mathrm{d}$ 点：燃焼終り 図 7 単一油粒の燃焼試験写真の一例 (照射 A重油 $700^{\circ} \mathrm{C}$ ) 
は，いずれも加熱炉内の空気温度に対する試料 0.2774 グラムの温度の示差を, 前者を横軸, 後者を縦軸とし て表わしている.この試験において試料は, 加熱炉内 の時間温度上昇に対し吸熱, 蒸発, 発熱の過程を経る ため, その示差温度は図のように変化する. 特にこの 変化で吸熱を伴う低温期間に注目すると, 各試料のそ れは負の方向に比熱に比例して下る曲線となることが わかる. しかし. 非照射 A 重油と照射 $\mathrm{A}$ 重油の比較に おいては, 両者まったくといってよいほどよく一致し ており，両者の間に比熱上の差が生じていないことが 理解できる.

図 4 のガスクロマトグラフィーの比較においては, 低沸点部分で, 非照射油と照射油の間にやや差が認め られるが, その他の部分では, 両者完全に一致してお り，主成分は何ら影響を受けていない，低沸点域で照 射油に現われている細かい現象の相 違は，超音波照射によって何らかの 変化を受けている油中の狭雑物が, 試料油の加熱時に熱分解したと思わ れるものであり,これより， $\mathrm{A}$ 重油 にこの程度のパワー（約 $10 \mathrm{~W} / \mathrm{cm}^{2}$ ) の超音波を照射しても, 分子の結合 が切れて低分子化することは，ほと んど起こらないものと判断される.

最近, 重油中には, 混合や貯蔵中 に生ずる酸化重合の所産として, か なりのスラッジを含むものが多く, ここに用いたA重油も例外ではな い.このような油に対する超音波の 照射効果を示したものが, 図 5 と図 6 の遠心沈殿試験とスポット試験の 結果である.

図 5 の遠心沈殿試験結果は, 試料 $100 \mathrm{cc}$ に, $428 \mathrm{Gal}$ 相当の遠心力を作 用せしめた場合のものであり, 非照 射油に対する照射油の沈殿量は, 照 射時間とともに明らかに少なくな る.しかし, $0.4 \mathrm{~h} / l$ 以上の長い照射 時間ではほとんど変らない。この結 果はスラッジを含む油に超音波を照 射すると, キャビテーション破壊に よって，スラッジが極微状態に粉砕 されて拡散し, 油がよりよく均質化 することを表わすものである.そし てこれはまた, 超音波処理油にさら に遠心分離清浄や沪過を加える必要
のないことを示すものである.

このスラッジのある油に対していえる上記試験結果 は, 同じ油に対する図 6 のスポット試験結果にも明り ように表われている．非照射油の場合は色の濃い丸い 斑こんが内部に小さく残るが，照射油の場合はこれが 薄く大きくなり，その程度は照射時間を増すとともに 顕著となってしだいに判別し難くなる.

\section{2 単一油粒の蒸発燃焼特性に及ぼす影響}

超音波処理油の蒸発燃焼特性を調べるため, 図 2 の 試験装置で行なった単一油粒の蒸発および然焼試験結 果を, その特性を明らかにする形で整理し, 非照射油 に対する結果とともに図 8 図12に示す.

図 8 および図 9 は，非照射 $\mathrm{A}$ 重油に対する照射 $\mathrm{A}$ 重 油の蒸発および燃焼特性曲線であり, 図10, 図11およ び図12は照射時間, 照射時の油温および照射後の放置

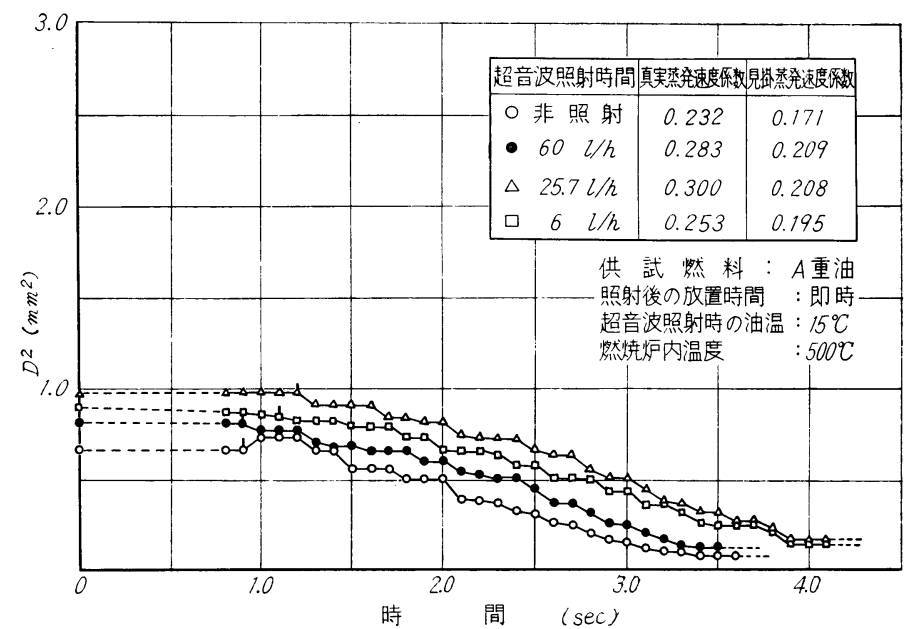

図 8 油粒 の蒸 発試験 結 果

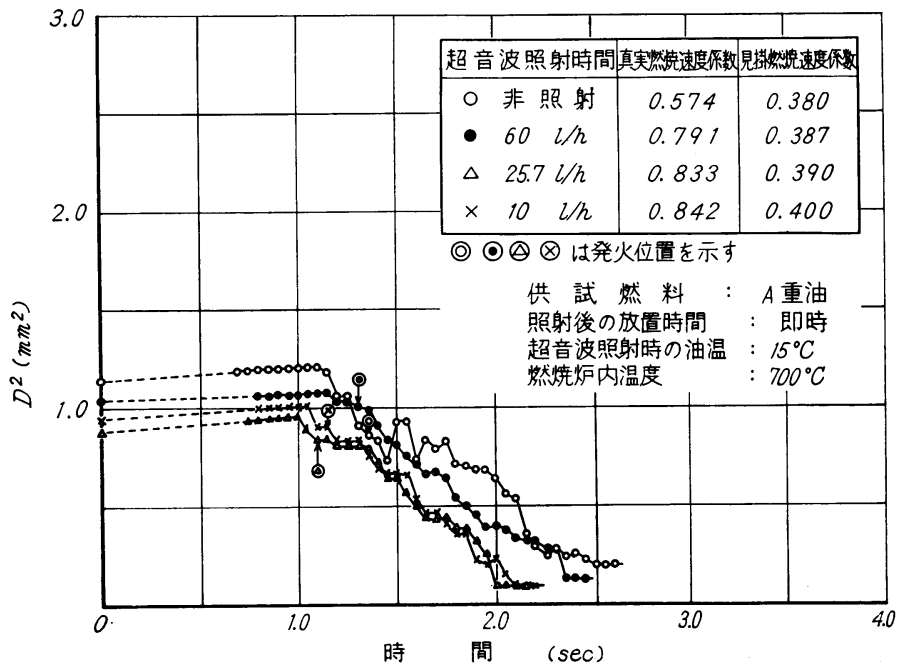

図 9 油粒の燃焼試験結果（照射時間の影響） 
時間の影響を C 重油について調べた燃焼特性曲線であ る.

各図はいずれも，図 7 に一部例示した採取高速度写 真より求めた油粒の換算直径の 2 乗の時間的変化を示 している. 図より原点を通る縦軸上の值が，炉内に入 る直前の油粒の大きさを示すことから，一定の高温炉 内中で受ける油粒の変化状態が明らかとなる. ここに 油粒の換算直径は，図 7 にみるごとく，一般にだ円体 となる油粒の占める体積と等しい体積を有する球に対 するもので，その換算はっぎの式によった。

$$
\mathrm{D}=\sqrt[3]{\mathrm{ab}^{2}}
$$

$$
\begin{array}{rll}
\text { ただし } & \mathrm{D} \text { : 換算球の直径 } & \mathrm{mm} \\
\mathrm{a}: \text { だ円油粒の長径 } & \mathrm{mm} \\
\mathrm{b} \text { : 同 上 短径 } & \mathrm{mm}
\end{array}
$$

図において，曲線の傾斜は蒸発ま たは焼燃速度係数を与え，供試油に 対するこれらの值は各図中に付記し たとおりである。このうち，見掛值 は，原点を通る縦軸上の点と蒸発ま たは燃焼終わりの点を結んだ直線の 傾斜に対するものであり, 真值は蒸 発または燃焼開始点（図中子，また はレ印で示す点）と，その終わりの 点を結んだ直線の傾斜に関するもの である。

炉内温度を $500^{\circ} \mathrm{C}$ 一定とした図 8 のA重油の結果によれば，油粒は時 間とともにゆるやかに小さくなって ゆく。これはこの温度で油粒が単に 蒸発のみで支配されるためである。 蒸発速度係数は真值も見掛值も極く わずかであるが，非照射油より照射 油のほうが大きくなる．また同じ照 射油でも，照射時間を長くしたほう が大きくなる傾向を示す

非照射油に対する照射油のこの傾 向は, 同じ $\mathrm{A}$ 重油およびC 重油に対 する図 9 および図10の燃焼試験の結 果についても同様である。しかし， 照射油と非照射油の間の速度係数の 開きは，上記蒸発試験結果よりも顕 著なものがある。これらは炉内温度 を $700^{\circ} \mathrm{C}$ に維持した場合の結果であ るが，油粒の大きさの時間的変化状 態は，A重油と C 重油とではかなり 異なっている．A重油の燃焼線はほ
ぼ直線的に変化するのに反し，C重油の場合は大きく 変動する. しかし，この変動の模様は，同じ油に対し てはまったく同じで，油粒の大きさに関係しない，し たがって，この形より油の産地や混合の内容を知るこ とが可能となる。

照射油に対する非照射油の油粒の大きさの時間的変 化の模様をみると，後者はかなりの凹凸を示しながら 小さくなってゆくが，前者は後者に比して凹凸も小さ く，スムーズに変化する。これは，超音波の照射を受 けて油中のスラッジが極微状に破砕，拡散して，より よく均質化されるために現われる結果と思われる。 油温を変えて超音波処理した油の燃焼速度保数は, 図11に示すごとく, $60^{\circ} \mathrm{C}$ の場合がもっとも大きく， それより温度が低くても高くても小さくなる，特に

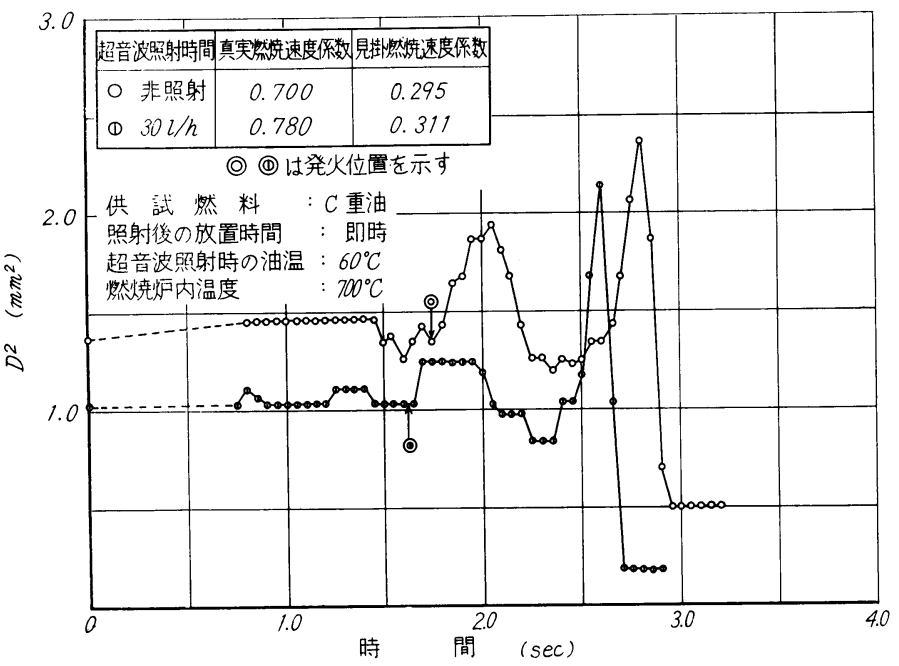

図10油粒の燃焼試験結果（照射時間の影響）

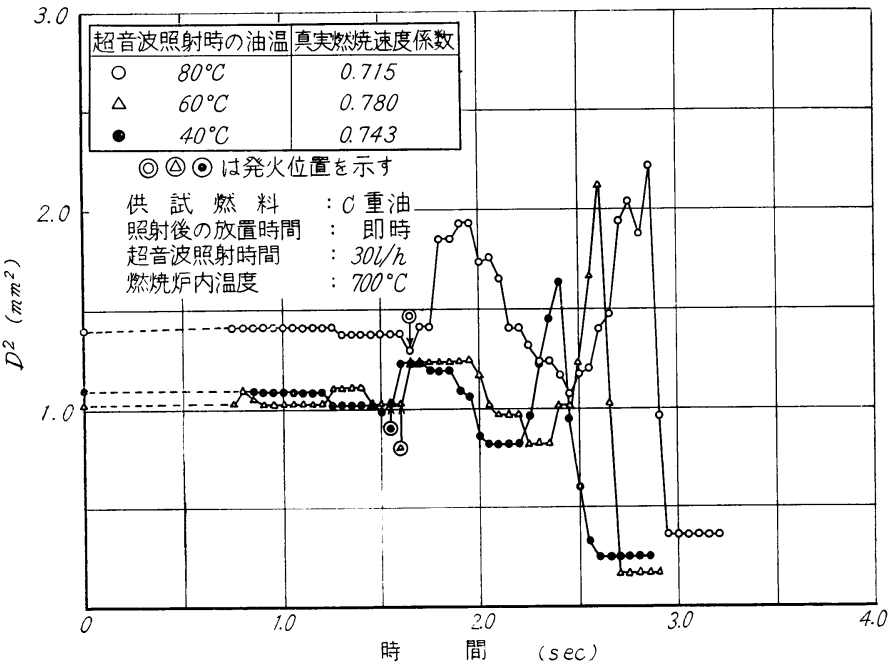

図11 油粒の燃焼試験結果（照射時の油温の影響） 


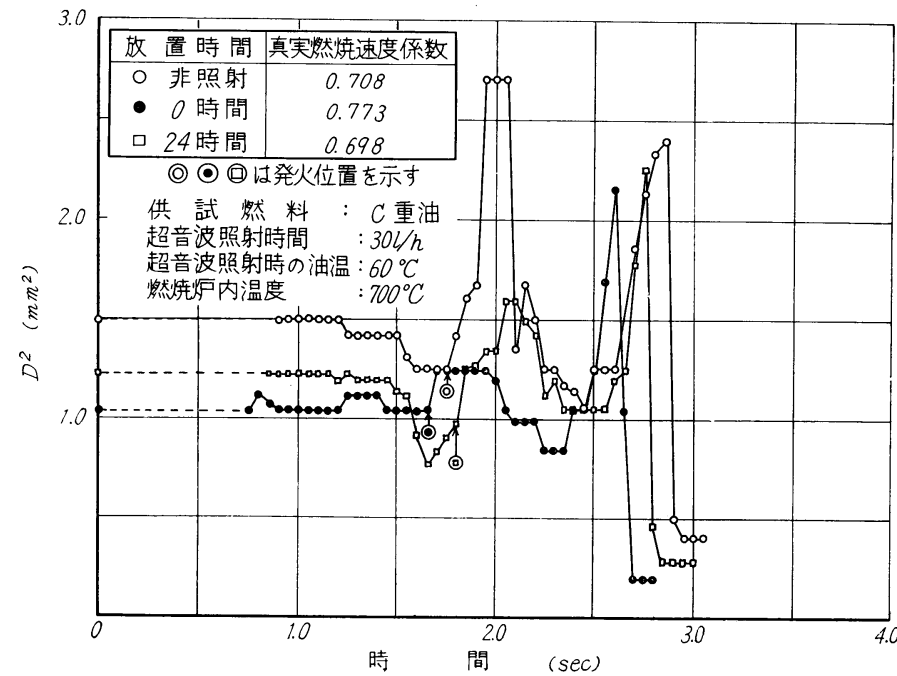

図12油粒の燃焼試験結果（放置時間の影響）
を増して，気泡の破裂力を弱め，ス ラッジが十分破壊されないためと思 われる。なお，この結果は Rosenberg らが, 水, 灯油,ベンゼンなど においてキャビテーション破壊と温 度との関係を調べている結果 ${ }^{(3)}$ とも 傾向的には類似している.

照射処理後の放置時間の影響につ いては, 図12に示すごとく, 燃焼速 度係数は処理直後の結果にくらべて 減少し，24時間放置のその値は非照 射の場合とほぼ同じくらいになる. これは照射処理後, 油中のスラッジ が徐々に元の状態にかえって行く結 果と思われる ${ }^{(4)}$.

\section{3 実機による使用試験結果}

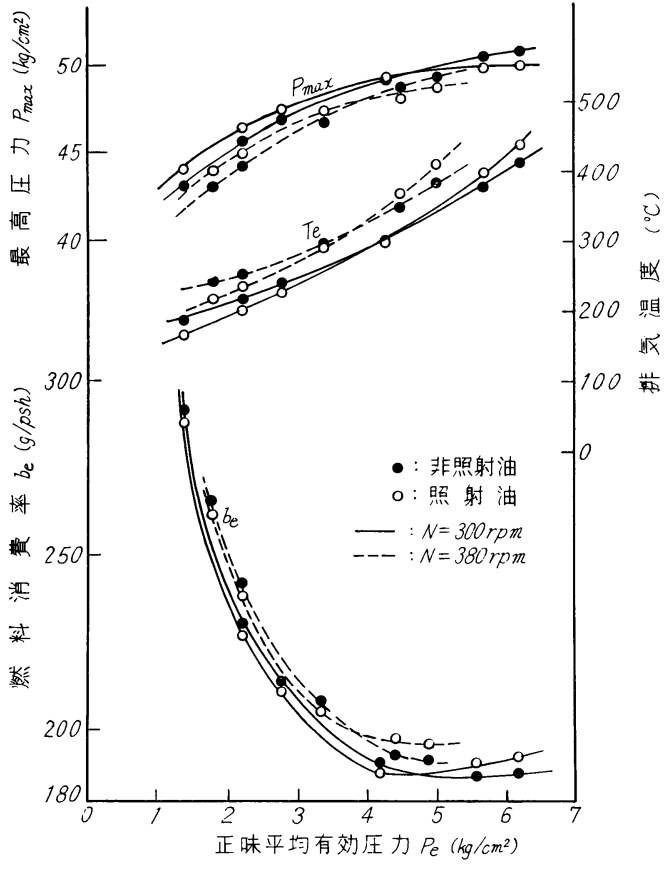

図13 実機試験 結 果

$80^{\circ} \mathrm{C}$ の場合は，非照射油の值と変わらない，これは 超音波キャビテーションの破壊効果が処理時の油温の 影響を受けて変わることを示すものであって，つぎの ように解釈される. すなわち， $60^{\circ} \mathrm{C}$ までの温度に対 しては, 温度の上昇とともにキャビテーション核の数 が増し, 溶解気体やその他の泡が発生して, スラッジ がよく粉砕されるが, $60^{\circ} \mathrm{C}$ 以上の温度では, 温度の 上昇につれて, 油中の蒸気および溶解気体がキャビテ ーション気泡内に混入し，いっそうの高温で気体弾性

以上の結果と実際機関との関連性を求めるため, 実 機における使用試験を, 照射 $\mathrm{A}$ 重油と非照射 $\mathrm{A}$ 重油に ついて行ない, 最高圧力, 排気温度および然料消費率 をもって比較し，その結果を図13に示した。

僅少ではあるが， $300 \mathrm{rpm} ， 380 \mathrm{rpm}$ とも，低負荷 領域では, 照射油使用の場合のほうが, 最高圧力は高 く, 排気温度は低くなって, 燃費は減少する。しかし, 高負荷領域におけるこれらの関係はまったく逆の状態 となる。

低負荷領域で照射油使用の場合に現われるこの有利 な結果は, 超音波処理することによって, 油がいっそ う均質化され，かつ，このような処理油においては， 前述のごとく蒸発速度係数も燃焼速度係数も大きくな ることおよびこの負荷は空気過剰率が大きいことから 予想できる当然の帰結といえる.

これに対し, 高負荷領域で超音波処理油が受ける不 利な結果は, 負荷の上昇に伴い, 噴射期間, 噴射量が 増して空気過剩率が下がるため, 上記速度係数の増加 は，大きな空気のうず流れを期待できない開放燃焼室 形においては, 噴射後半の噴霧に対しては局所的にか えって過濃混合気を形成する傾向にあり，このような 結果を招いたものと思われる。

\section{5. をとめ}

一つの超音波処理装置で, 市販の重油を照射時間や 照射時の油温を種々変化して処理した場合の効果につ いて, 実験的に調べた以上の結果は, つぎのごとく要 約できる.

（1）スラッジの多い油を超音波処理すれば, 油中 のスラッジは破砕，分散して油は均質化される. 
（2）本装置がもつ程度の超音波を照射しても，燃 料の比重, 粘度, 表面張力はほとんど変わらない.

また，炭化水素の分子間の結合が切断されて低分 子化することも比熱の変化も見られない.

（3）供試油の蒸発および然焼速度係数は，超音波 の照射によってやや大きくなる，試験範囲における その程度は照射時間を増すほど顕著となる.

（4）照射処理後の放置時間の影響については，放 置中に油は初めの状態にかえる傾向があるので, 放 置時間の長いほど然焼速度係数は減少する.

（5）照射時の油温の影響については, 最大のキャ ビテーション破壊を示す最適油温が存在する.

（6）うず流れの小さい直接噴射機関では照射処理 した油の低負荷領域における燃料消費率は非照射油
使用の場合に比し少なくなるが，高負荷領域ではか えって多くなる. しかし, これらの差はきわめて僅 少である.

終わりに臨み, 示差熱分析器の使用に際しては本学 化学教室の青木教授, 広井教官のご協力を得, ガスク ロマトグラフの使用については島津製作所の研究所の 厚意を受けた. また, 器材などの一部は, 栗林商船会 社および旭興業会社の提供によった. 記して感謝の意 を表わす.

\section{文献}

(1) KAYSEVEN NEWS, No. 1, No. 2 (昭 41-3, 5)

（2）小林清志, 日本機械学会論文集, 20-100 (昭 29), 826 843.

（3） Rosenberg，超音波入門 (上田光隆訳), 31, 東京図書

（4）柳沢 亘, 日本舶用機関学会誌, 1-4 (昭 41$), 141$

その他, 超音波技術便覧, 改訂新版 (昭 41), 日刊工業新聞社

\section{[質疑 応 答】}

\section{質問者 東京商船大学 内海 博}

〔質問 1】超音波を照射した直後の試験結果と長時 間放置したそれとはどう異なるか。 また，それはどう してか.

[質問 2]あまり変化がないと考えられた粘度, 比 重, 表面張力, および比熱を調べ, かつガスクロマト グラフィーを行なった理由はなぜか.

[質問 3 ] 図 5 において, スラッジの量は分散前後 においても変化しないと思われるが, 状態の変わって いるのはなぜか。

[質問 4]一口にA重油， C 重油といっても，その 燃焼性は原油, 精製法, 混合基油によって大いに異な るものがある.この観点より図 9 および図10の説明は， やや一般的でないと思われるがどうか.

〔回答 1] 超音波照射による燃焼性の改善は，油中 の阻害物質を取除く方法によるのではなく, 存在せし めたまま極微状に粉砕拡散せしめて均質化し, 燃えや すくすることであり，結果的には物理的破壊によって いるから, 長時間放置すれば元の状態にかえるものと 考えてよい. その結果の一例は, 図11に示すとおりで ある。

〔回答 2〕性状の異なる油を種々混合して作られて いる重油に超音波を照射した場合, そのキャビテーシ ョン破壊によって, もし炭化水素の分子間の結合が切 断されて低分子化するようなことがあれば物性変化を きたすことが予想される。物性変化のうち比熱は発火 遅れに関係し, 粘度, 表面張力は微粒化に影響するも のであり，ディーゼル機関のシリンダ内における燃焼 性能を取扱うためには一応調べてみる必要がある。も
とより，超音波の照射によって油全体に著しい変化が 起こることは予想していなかったが, 微少な变化でも 起こる場合にはこれを正確に見出す必要があり, 前述 したような各種の実験を行なったのである.

[回答 3] スラッジの形成については, 質問者が本 会会誌（第 1 巻， $1 ， 2$ 号, 昭42）でのべている見解 によりたい. しかし, 形成されたスラッジには, 超音 波照射によって容易に粉砕される軟質, 軟硬質のもの もあれば, 破壊困難な硬質のものもある。また，これ が油中に存在する仕方には, 重くて沈降するものもあ れば, みかけ上比重が軽いため浮遊懸垂するものもあ る。このような油に超音波を照射すると, 照射時間に よって照射エネルギの受け方が変わり粉砕拡散の程度 が異なるので,一定条件の遠心沈殿試験のもとでは, 図 5 のように沈殿スラッジ量が変化する.

[回答 4]区分名称上 $\mathrm{A}$ 重油, $\mathrm{C}$ 重油といっても, その内容は原油, 精製法, 混合基油によって異なり燃 焼性に影響することは指摘のとおりである。図 9 , 図 10の結果に対する見解は, 広範囲の A 重油, C 重油に 対するものでなく, 試用した一つのA重油, C 重油に 超音波を照射した場合とそうでない場合の結果を述べ ているものである。

なお,われわれは別な実験目的で, 各種の重油につ いて単一液滴の燃焼実験を行なっているが, その結果 によれば, 発火から燃えつきるまでの曲線の形は, C 重油の場合は図10のごとく, 大きく凸出する山が始め と終りにくるものもあれば,始めに大きくなるもの, ま たは終りのみ大きくでてくるものもある.しかし, 一 つの油に対するこの形は, 油粒の大きさに関係なく相 似である。このことはA重油についても同様にいえる が，C重油ほど顕著な形の变化はなく，いずれも図 9 に示す程度である。 